\title{
From the Point of View of Ready-to-Wear Industrial Practices of the Vocational High School Students Getting Clothing Education in Turkey
}

\author{
Nurgül K1lınç and Meral Akkaya \\ Seljuk University, Marmara University, \\ Turkey
}

\section{Introduction}

Vocational training is the process of cultivating the individual intellectually, emotionally, socio-economically and personally in a balanced way, furnishing the individual with the knowledge, ability and practical applications that are accompanied by a certain vocation that is required for individual and social life (A ğaç, 2004). While scientific and technological improvements play an important role in the labor market, vocational training maintains its key role in preparing individuals for a profession. The increasing automation practices in the process of manufacture, high level specialization, rapid progress in technical knowledge and abilities and so on have led the vocational training assume a new quality (Alkan\&Doğan\&Sezgin, 2007).

In the modern sense, processes of vocational training have such peculiar features as constant conformity to improvements, social orientation, and the need for time and technology for its practices, provision of a real vocational life setting. It has been established through practices that, for the schools which are in direct connection with the rapidly changing technology to achieve their objectives, the training offered should be supplemented by real workplace circumstances and that such a supplement leads to fruitful results. For these reasons, it is regarded as imperative that, for labor force to be qualified, the students who have acquired basic knowledge and abilities at vocational and technical training institutions should perform their laboratory and workshop practices in real settings of manufacture.

Vocational training in Turkey, according to the Apprenticeship and Vocational Training Law no. 3308, stipulates that three days of the week should be spent on skill training in corporations for industrial vocational high schools, vocational high schools for girls and high schools for commerce and that two days of the week should be spent on theoretical training at school. At vocational training schools on secondary level, training is carried out in accord with this law (Gürol, 1997). The law no. 3308, which regulates the relationships between schools and industries, and the regulations that were laid down for the implementation of this law have assured the establishment of new concepts, new functions 
and new structures in the training that is based on collaboration between schools and workplaces.

This system, which is conducted at secondary level vocational training schools and which is based on the cooperation of schools and workplaces, is called the dual system. This is a system which schools and the workplaces conduct together with the school curriculum on a basis of mutual cooperation and which combines work and training in order to achieve predetermined objectives. Within the system, students usually spend one or two days of the week at schools and three or four days at workplaces working. During the working period at workplaces, students are insured by the state against job accidents and job-related diseases, and he/she is paid a certain amount in return for the work. (Şahinkesen, 1991).

The training program which schools and corporations carry out in cooperation is based on the principle that it must be conducted in cooperation with corporations and that the corporations must contribute to the solution of training-related problems. The need for the training in a certain area can be most appropriately fulfilled through participation from the corporations in the area. The training that schools and corporations conduct in cooperation requires the involved public executives, those in authority at training institutions, employers and labor corporations, private and public representatives to participate in the decision-making process during the stages of planning, executing and developing vocational training (Gürol, 1997).

\section{School-Industry Relations in Vocational Training at Secondary Level Education}

Training not only develops the required number of labor sources with the required qualifications for development, but also has regulatory impacts on labor market, and balances the supply and demand of labor. Although the demand for labor depends on investment, supply of labor is concerned with trained labor force. To increase productivity and to make the element of labor more efficient in development depend on training. The investment by industrial corporations in labor-related training, as well as the goods they manufacture, is of great importance also in improving the human factor, which is directly related to the increase in productivity and quality (Topal, 1995).

Vocational training is a process of education which is a balanced combination of dimensions of individual, profession and training, and aims at the improvement of the individual in all respects. The main purpose of vocational training is to bring forth desired behavior, to establish a training environment, and to help acquire the required knowledge and skills in theoretical and practical fields. Vocational training is society-oriented, employment-based, inclusive of all levels of training, and integrative of theory and practice with work (Şahinkesen, 1991). At whatever level and with whatever quality a training program is implemented, the school has to establish a sustainable relationship with the industry. The sound relationships that institutions of education will establish with the industry and sectors will both secure their own existence and help their programs acquire more functional properties (Gürol, 1997).

The education at schools is mostly composed of the cognitive parts of the practices in working life. The knowledge taught and the abilities imparted at school form a substantial phase of the phenomenon of education. With the realization of this phase, the first and primary step is taken so as to bring forth the labor force qualified to work in the industry 
(Kuru, 2006). In order to fully provide the required training of the labor force and to acquire adjustment and vocational proficiency, it is necessary to make prevalent the training services offered at workplaces in parallel to the one offered at schools and to realize this prevalence to a large extent especially in secondary and post-secondary levels (Kilınç, 2004). At secondary school, the cooperation of school-industry must be established. The curricula covering the requirements of the industry must be developed. The students must be provided with employment after graduation. The employers must contribute to training. These and others are the factors that require the cooperation of schools with industry at secondary school level.

\subsection{The Development of School-Industry Relationships in the World and in Turkey}

Training programs based on the cooperation of school-industry are implemented in many countries under different names. For example, these programs are called "Block Release" "Sandwich Course" and "Part time" in England, "Dual System" in Germany, and "Cooperative Education" in the United States of America. In various periods in Turkey, vocational training programs based especially on the cooperation of vocational secondary schools and industry have been implemented under such different titles as Intensive Training, School-Industry Cooperative Training Project, Vocational and Technical Training Project, and Vocational and Technical Training Improvement Project (Günceoğlu, 2003). Such training practices were first implemented in Akhi associations in Turks in the 13 ${ }^{\text {th }}$ century. In Akhi associations, every group of vocation targeted to make their members equipped with a common pattern of behavior peculiar to that vocation. They have occupied a primary place in the history of education in Turkey.

The candidates who were affiliated into Akhism were trained for the way of living required by that vocation by a qualified master or by a council of masters in a father-son relationship at work during the day, while in the evenings they were trained regarding the knowledge of humans and commerce in dervish lodges (Ekinci, 1990). A similar practice was initiated in England in the 19th century (1865). The children who worked at factories were made to attend schools half-day. (Alkan and others, 1998). However, in Germany during the period when the lodges' system was abolished in the other European countries, the research in the institution of political sciences led to the conclusion that the lodge system had lost its characteristics and as a result, Dual System was recommended in 1897 and was put into effect. With the same purpose, France has been using an education system combined under the name of "Systems of Mixed of Education" since 1961 (Şahinkesen, 1991).

Cincinnati University in America occupies a special place in the historical development of cooperation. For the Dean of Engineering Faculty, Prof. Dr. Herman Schneider, concluded that if students spent some of the time in workplaces they spent at schools, which are real places of training, this could enable them to be better prepared. Prof. Dr. Schneider believed that most professions couldn't be sufficiently taught in classroom settings and that students could only learn practical skills at workplaces. With this plan of his, students started to earn money as well as skills in 1906. Ten high schools in the field of engineering joined in this training between 1906 and 1919, which was called cooperative training. In 1919, the first training program was launched at university in the field of commerce and accounting outside technical fields, and in 1921 the first cooperative program was established in the field of Social Sciences at Antioch College (Kraska, 1995). 
These cooperative programs were rapidly adopted following the Second World War, expanding their field of practice and becoming common. For instance, with the laws passed in the USA in 1968 and 1976, all institutions of education were encouraged to improve their relationships with public and private enterprises, and this was in a way made compulsory for some vocational and technical training institutions (Gürol, 1997).

\subsection{The Goal of School-Industry Cooperation}

In every system of education there are defined goals. The programs implemented in vocational training system and the cooperation of school with industry aim to acquire mutual responsibility, to make best use of the available sources, to serve for the youth and the society, to enrich the existing opportunities of education, and to make education functional (Erkal, 1978;Kappler, 1991; Schmidt, 1991).The goals are outlined as follows;

1. To make learning more meaningful and functional, to fill in the gap between theory and practice, and to integrate classroom studies into real working conditions.

2. To reach the capacity to follow the new technology and utilize it.

3. To provide the opportunity to improve general and specific professional skills, habits, knowledge and behavior.

4. To conduct the necessary coordination between the school and the workplace to provide the desired training by joining in the activities in social and economic bodies.

5. To create financial opportunities for the students unable to continue their education for economical reasons.

6. To create the opportunity for training in private branches of the profession.

7. To facilitate adjustment to the transition from school to working life.

8. To make use of human sources of the society and that of the industry.

9. To contribute to the maintenance of the balance of supply and demand.

10. To enlarge the extent of education services.

\subsection{The Parties Involved in the Cooperation between School and Industry in Secondary School Education and the Benefits Offered to These Parties}

The school-industry cooperation should be established and maintained permanently in Secondary School Education. This is of great importance for the continuity of the cooperation. The parties that will provide this cooperation can be divided into two subgroups as direct and indirect ones.

The Indirect parties involved are; governmental organizations, educators, industrialists, labor unions, chambers of professions, craftsmen associations and mass media. The direct parties involved are; consultation boards, center of Ministry of Education, the school management, the coordinator teacher, corporations, the training staff, students and custodians.

The benefits derived from the school-industry cooperation can be classified into 6 groups. These are;

- The benefits provided for the state,

- The benefits provided for the students,

- The benefits provided for the schools, 
- The benefits provided for the corporations,

- The benefits provided for the society (environment),

- The benefits provided by the programming,

\section{The Benefits Provided For the State}

The dual training system conducted at schools and in industries contributes greatly to eligibly and economically meeting the demand for qualified labor force in all sectors in which fierce competition exists globally (Ulusoy, 2004). Also, it has a part to play in reducing one of the most significant problems in countries, that is, the problem of unemployment (Erkan, 1995).

\section{The Benefits Provided For the Students}

- It offers training in real working places or in conditions similar to those in real working places.

- It enables them to see the result of the work done in the working place and in the way it is used.

- It offers the opportunity to get to know the industry-manufacture and management scheme and to draw nearer to it.

- It creates the opportunity to develop their knowledge of and experience in such matters as employee-employer relationships, social rights and solidarity of employees, wage, tax and management.

- By enabling them to see the developments in industry and the methods applied instantly and on the spot, it shortens the duration of adjustment to working life after graduation.

- It enables them to make more reasonable decisions about their future before graduation.

- They see the importance of skills and experiences in real working environment. By seeing that the individuals with the same level of education but with different skills obtain different statuses, they pay attention to gaining skills while still at school (Doğan and others, 1997).

- They are paid a wage by employers no less than minimum wage (Kaya, 2004).

- It integrates theory into practice.

- It increases the prospects of finding a job (Gürol, 1997).

\section{The Benefits Provided For Schools}

- Because the practices are conducted in workplaces, the investments to be made in laboratories and workshops decrease.

- The rate at which to utilize training staff increases (Şahinkesen, 1991).

- Schools obtain the possibility to receive help regarding industry, tools, equipment, financial support and exchange of staff.

- The cooperation diversifies learning, and it increases capacity.

- Schools obtain the possibility to compare the programs they offer with real working life.

- Schools increase the opportunities for individual learning (Doğan and others, 1997).

- Schools follow the technological innovations and developments in industry closely and thus take necessary measures. 
The benefits provided for the corporation

- With the skill training of the qualified labor force required by the industry, the Dual System enables the corporations to be developed in a real environment of interaction.

- With the participation of students in the labor force, productivity increases.

- The financial burden on the employer decreases as the state pays the insurance premiums for the students who are in the training program working at the workplace.

- The fact that the students who receive vocational training join in the practices with new knowledge during the period of training leads to a rise in the quality of production and helps increase the productivity (Kaya, 2004).

- The corporations share the responsibility by joining in vocational training.

- They obtain the possibility to recognize the students who receive training at the workplace and to choose qualified staff from among them (Şahinkesen, 1991).

- They make use of the cooperation with the instructor trainer.

- The needs of the industry are reflected while training programs are developed (Gürol, 1997).

- $\quad$ They benefit from a comeback of the taxes they pay (Doğan and others, 1997).

The benefits provided for the society (environment)

- From an economical point of view, the Dual System equips the society with vocationally qualified individuals.

- By preparing youngsters for professions, it reduces unemployment and makes them productive.

- It establishes the ground for cooperation between the institutions of the society in order to prepare youngsters for life and work (Gürol, 1997).

- Youngsters are closely familiar with the local needs; they are raised in accordance with the local needs and thus they stay in the province (Doğan and others, 1997).

The benefits provided with respect to programming

- Training programs are revised and developed in accord with the needs of the industry (Gürol, 1997).

- The system makes learning more functional.

- It offers the possibility to integrate theoretical training into life and application.

- It also offers the possibility to keep the program constantly dynamic and to follow the improvements.

As well as the great many benefits mentioned above, various problems arise when the conditions required by law cannot be provided and when structural reforms do not take place. Some other problems are also observed to have emerged since 1986, when the law went into effect, due to the behavior of those involved, the training system and the lack of physical environment (Doğan and others, 1997).

\subsection{The school-Industry Relationships in Clothing Training in Terms of the Ready-to- Wear Sector}

One of the sectors in which production is the most intense in fashion sector and which is of great importance to the economical development of Turkey is ready-to-wear clothing sector. 
The ready-to-wear clothing sector, with a large share in Turkey's exports, is at the same time the branch of industry with the largest employment rate. In Turkey, both those who are employed in the manufacturing of ready-to-wear clothing and the ones who are engaged in the trade of these items account for a third of all the employed, excluding the sector of agriculture, and one fifth of all the industrial workers. The magnitude of this figure results from the labor-intensive character of the sector. The fact that division of labor requires employees equal to the number of the processes particularly in the manufacturing of readyto-wear clothing intensifies the need for the labor force in the manufacture of clothing, which is made up of many processes (Koç, 2006).

In ready-to-wear clothing sector, in which fierce competition is experienced on a global level, qualified labor force is definitive in the competition in this field. Especially for the Turkish ready-to-wear clothing sector, which targets to manufacture quality and expensive items with a high added value, qualified labor force is of greater significance.

Because the body of knowledge that the labor force in ready-to-wear clothing corporations has reveals the defining characteristics of the corporation, human sources constitute the landmark of success in the competitive atmosphere of the free market economy. In Turkey with a young population, trained and qualified labor force is undoubtedly needed for the rapidly changing technology of ready-to-wear clothing to function efficiently, which is a labor-intensive sector. It lies with the vocational training institutions to raise human force to be offered to the ready-to-wear clothing sector in the best way, considering the needs of the sector, and for this human force to meet the needs of the sector (İmer, 2007).

Training directed to the ready-to-wear clothing sector is offered in Turkey in various institutions of education at university level and at formal and informal institutions of education at high school level. The basic goal in the training offered is to raise qualified staff for the sector which exists in the country and which has achieved a remarkable success up to the present. If the corporations which operate in the sector and which host these industrial practices assess the success of this dual system, which is implemented to raise qualified labor force needed by the sector with the support from the workplaces and to what extent the targets are reached, the results will be more realistic. For this reason, this survey covers the assessment of industrial practices which involve training and which the ready-to-wear clothing corporations have conducted together with vocational high schools.

\section{The Method}

The purpose of this survey is to reveal the assessments on one hand of the training which the students of vocational high schools at secondary education level under the Ministry of Education in Turkey carry out in industry in accord with the law no. 3308 and on the other of the industrial practices by the ready-to-wear clothing corporations.

Survey method was used in this study, which covers the assessment of industrial practices of the students who receive training in clothing in Turkey.

The scope of the survey is the ready-to-wear clothing corporations in which vocational high school students carry out industrial practices required by law and the program.

The sampling of the survey was identified as the 58 corporations where the students at the last grade who received training in clothing attended for training practices in the cities of Adana, Ankara, Aydın, Balıkesir, Istanbul, Izmir, Sakarya and Tekirdag. While choosing the sampling, those in the management at vocational high schools offering training in clothing 
under the Ministry of Education were consulted, and the corporations in which the students carry out industrial practices were determined.

The distribution of ready-to-wear clothing corporations according to the number of employees in the sampling of the survey is given in Table 1.

\begin{tabular}{|l|l|l|}
\hline The number of employees & $\mathbf{f}$ & $\%$ \\
\hline Fewer than 20 & 14 & 24.1 \\
\hline $21-30$ & 2 & 3.4 \\
\hline $31-50$ & 7 & 12.1 \\
\hline $51-100$ & 15 & 25.9 \\
\hline $101-200$ & 3 & 5.2 \\
\hline More than 200 & 17 & 29.3 \\
\hline TOTAL & 58 & $\mathbf{1 0 0 , 0}$ \\
\hline
\end{tabular}

Table 1 . The distribution of ready-to-wear clothing corporations per employees in the sampling of the survey

One of the frequently used criteria in determining the scale of the survey was also the number of employees. When the distributions of the ready-to-wear clothing corporations according to the number of employees are examined, it is seen that both small-scale and medium-scale and large scale corporations are included in the survey.

A questionnaire form which was developed by the researchers was used to collect the data for the survey. In the process of developing the questionnaire form, the literature which is related to the issue, the vocational training law no. 3308 and the regulations prepared for the implementation of the law were taken into consideration.

Finally the form was modified after a control application. The data collected through the questionnaire were classified and presented in bilateral tables. In the arithmetical means, which were calculated as regards the levels of proficiency that, according to the corporations, students had about their professions, the grades between 1.00 and 1.80 were accepted as very poor; the ones between 1.81 and 1.60 as poor; those between 2.61 and 3.40 as medium; the ones between 3.41 and 4.20 as good and those between 4.21 and 5.00 as excellent. The evaluations were made according to these mean values.

\section{The evaluation of the Students at Vocational High Schools in Turkey Which Offer Training in Ready-to-Wear Clothing by Corporations}

In this section, the findings collected from ready-to-wear clothing corporations involved were presented under five headings.

\subsection{The Level of Knowledge and the Behavior in Ready-To-Wear Clothing Corporations towards Industrial Practices}

The most important duty of vocational training is to raise the qualified labor force necessary for development. In recent years, legal arrangements have been introduced besides imposing social responsibilities on the corporations which will employ this labor force as well as those on the schools to raise a qualified labor force required by the industry. The distribution of the frequency with which the corporations, which operate in ready-to-wear 
clothing sector and which open factories and workshops for industrial practices of vocational high schools, establish regular relationships with schools, is given in Table 2.

\begin{tabular}{|l|l|l|}
\hline $\begin{array}{l}\text { The frequency with which the corporations establish } \\
\text { regular relationships with schools }\end{array}$ & f & \% \\
\hline Always & 15 & 25,9 \\
\hline Generally & 22 & 37,9 \\
\hline Sometimes & 13 & 22,4 \\
\hline Seldom & 7 & 12,1 \\
\hline Never & 1 & 1,7 \\
\hline TOTAL & $\mathbf{5 8}$ & $\mathbf{1 0 0 , 0}$ \\
\hline
\end{tabular}

Table 2. The distribution of the frequency with which the corporations establish regular relationships with schools

When the ready-to-wear corporations that allowed industrial practices were asked whether they established regular relationships with schools, $38 \%$ of them replied that they generally established relationships, and $26 \%$ replied that they always established such relationships. Only $12 \%$ of the corporations expressed that they seldom established such relationships with schools, while $1.7 \%$ replied as never. Judging from Table 2, it can be concluded that corporations establish regular relationships with schools.

The distribution of the awareness of the corporations involved in the survey about the law no. 3308 and about the adjustments made in the regulation for vocational and technical training is given in Table 3 .

\begin{tabular}{|l|l|l|}
\hline The awareness of the corporations about legislation & \multicolumn{2}{|c|}{ corporation } \\
\cline { 2 - 3 } & f & \% \\
\hline Yes, we are aware & 27 & 46,6 \\
\hline No, we aren't aware & 31 & 53,4 \\
\hline TOTAL & $\mathbf{5 8}$ & $\mathbf{1 0 0 , 0}$ \\
\hline
\end{tabular}

Table 3. The distribution of the awareness of the corporations about the industrial practices in the law and its regulations

When Table 3 is examined, it is seen that only $46 \%$ of the corporations are aware of the legal arrangements as regards industrial practices. This shows that, although ready-to-wear clothing corporations allow industrial practices to be conducted in their workplaces, they significantly lack in knowledge of their rights and liabilities regarding these practices. This situation will adversely affect the quality of industrial practices and productivity. For this reason, steps are required to be taken to eliminate this lack of knowledge.

The distribution of the ways in which ready-to-wear clothing corporations decide on the students who will do industrial practices is presented in Table 4.

\begin{tabular}{|l|l|l|}
\hline The ways to decide on the students for industrial practices & f & $\%$ \\
\hline We accept the students specified by the school & 33 & 56.9 \\
\hline $\begin{array}{l}\text { We accept students who apply according to the order of the date of } \\
\text { their applications }\end{array}$ & 2 & 3.4 \\
\hline
\end{tabular}




\begin{tabular}{|l|l|l|}
\hline We decide according to certain criteria & 21 & 36.2 \\
\hline Others & 2 & 3.4 \\
\hline TOTAL & $\mathbf{5 8}$ & $\mathbf{1 0 0 , 0}$ \\
\hline
\end{tabular}

Table 4 . The distribution of the ways in which ready-to-wear clothing corporations decide on the students who will do industrial practices

According to Table 4, $57 \%$ of the ready-to-wear clothing corporations expressed that the students who would do industrial practices in their own corporations were determined by the vocational high schools. $36.2 \%$ of them replied that they themselves decided on the students according to the criteria of their own. As a result, it can be said that, in most cases, the students who will do industrial practices in the ready-to-wear clothing corporations are determined by the schools.

The distribution of the criteria, with which the corporations determine the students who will be accepted for industrial practices is given in Table 5 .

\begin{tabular}{|l|l|l|}
\hline $\begin{array}{l}\text { The criteria with which the corporations determine the students who } \\
\text { will be accepted for industrial practices }\end{array}$ & $\mathbf{f} \%$ \\
\hline Gender & - & - \\
\hline The end-of-the year average of their school grades & 14 & 22.3 \\
\hline According to what class the student is at & 5 & 8.0 \\
\hline According to the school of the student & 10 & 15.9 \\
\hline The absenteeism of the student at school & 7 & 11.2 \\
\hline $\begin{array}{l}\text { The suggestions by the coordinator instructor of the school of the } \\
\text { student }\end{array}$ & 15 & 23.5 \\
\hline The proximity of the school of the student to the workplace & 12 & 19.1 \\
\hline TOTAL & $\mathbf{6 3}$ & $\mathbf{1 0 0 , 0}$ \\
\hline
\end{tabular}

Table 5. The distribution of the criteria, with which the corporations specify the students who will be accepted for industrial practices

While determining the students who would come to their corporations for industrial practices, $22.3 \%$ of the ready-to-wear clothing corporations replied that they took the school grades of the students into consideration. $23.5 \%$ of them gave priority to the suggestions by the coordinator instructors. The most important point that draws attention in Table 5 is that gender isn't among the criteria that are used to determine the students for industrial practices. This can be thought to be a result of the structural characteristics of the ready-towear clothing sector. As is known, the ready-to-wear clothing sector is among the sectors in which both male and female workers can work.

The data concerning the distribution of the reasons that require the cooperation between schools and the industry according to the ready-to-wear clothing corporations are given in Table 6.

\begin{tabular}{|l|l|l|}
\hline $\begin{array}{l}\text { The reasons that require the cooperation between schools and the } \\
\text { Industry }\end{array}$ & $\mathbf{f}$ & $\mathbf{\%}$ \\
\hline To contribute to the development of training programs at schools & 24 & 13,8 \\
\hline To provide qualified labor force for private sector & 38 & 21,8 \\
\hline
\end{tabular}




\begin{tabular}{|l|l|l|}
\hline $\begin{array}{l}\text { To make students acquire knowledge, skills and attitude as regards their } \\
\text { profession }\end{array}$ & 51 & 29,4 \\
\hline To help students develop a sense of self-confidence in his profession & 30 & 17,2 \\
\hline To facilitate the adjustment by students to novelties and developments & 30 & 17,2 \\
\hline Others & 1 & 0,6 \\
\hline TOTAL & $\mathbf{1 7 4}$ & $\mathbf{1 0 0 , 0}$ \\
\hline
\end{tabular}

Table 6 . The distribution of the reasons that require the cooperation between schools and the industry according to the ready-to-wear clothing corporations

As the reasons that require the cooperation between schools and the industry, $29 \%$ of the corporations expressed that their first motive was to make the students acquire knowledge, skills and attitude as regards their professions. $22 \%$ of them ranked the provision of qualified labor force at the second place. At the third place came the development of a sense of self-confidence and adjustment to the novelties and developments with a percentage of 17.

The data about the distribution of the positions of those that directed the industrial practices of the students in the corporations involved are given in Table 7.

\begin{tabular}{|l|l|l|}
\hline $\begin{array}{l}\text { Positions of those that managed the } \\
\text { industrial practices of the students }\end{array}$ & $\mathbf{f}$ & $\mathbf{\%}$ \\
\hline Corporation executive & 8 & 13,8 \\
\hline Manufacturing executive & 6 & 10,3 \\
\hline Chiefs & 11 & 19,0 \\
\hline Personnel manager & 8 & 13,8 \\
\hline Master instructor or trainer & 22 & 37,9 \\
\hline Others & 3 & 5,2 \\
\hline TOTAL & $\mathbf{5 8}$ & $\mathbf{1 0 0 , 0}$ \\
\hline
\end{tabular}

Table 7. The distribution of the positions of those that managed the industrial practices of the students in the corporations involved.

When Table 7 is examined, it is seen that in almost $38 \%$ of the corporations, master instructors or trainers, in $19 \%$ of them, chiefs, in almost $14 \%$ of them the corporation executive and again in almost $14 \%$ of them the personnel manager, in about $10 \%$ manufacturing executive directed the industrial practices of students.

That the people who directed the conducted industrial practices were in different positions resulted from the structural differences and scales of the corporations. In large-scale corporations, special trainers were authorized for industrial practices, whereas in smallscale corporations this duty was at the hands of the executives of the corporations.

\subsection{The Comparison of Vocational Proficiency of the Students Who Carry Out Industrial Practices in Ready-To-Wear Clothing Corporations before and after the Practice}

According to the corporations involved in the survey, the levels of the students to have proficiency in their branches are given in Table 8. 


\begin{tabular}{|c|c|c|c|c|c|c|c|c|c|c|c|c|}
\hline \multirow{2}{*}{$\begin{array}{l}\text { Proficiency of the } \\
\text { students }\end{array}$} & \multicolumn{2}{|c|}{$\begin{array}{l}\text { Very } \\
\text { poor }\end{array}$} & \multicolumn{2}{|c|}{ Poor } & \multicolumn{2}{|c|}{ Medium } & \multicolumn{2}{|c|}{ Good } & \multicolumn{2}{|c|}{ Excellent } & \multirow[t]{2}{*}{$\overline{\mathbf{x}}$} & \multirow[t]{2}{*}{ Ss } \\
\hline & f & $\%$ & f & $\%$ & $\mathrm{f}$ & $\%$ & $\mathrm{f}$ & $\%$ & $f$ & $\%$ & & \\
\hline To design models & 4 & 6,9 & 10 & 17,2 & 26 & 44,8 & 15 & 25,9 & 3 & 5,2 & 3,05 & 0,96 \\
\hline $\begin{array}{l}\text { To prepare computer- } \\
\text { based drafts and patterns }\end{array}$ & 4 & 6,9 & 11 & 19,0 & 14 & 24,1 & 24 & 41,4 & 5 & 8,6 & 3,25 & 1,08 \\
\hline To prepare a collection & 3 & 5,2 & $\overline{10}$ & 17,2 & 24 & 41,4 & 19 & 32,8 & 2 & 3,4 & 3,12 & 0,91 \\
\hline To prepare patterns & 1 & 1,7 & 11 & 19,0 & 21 & 36,2 & 19 & 32,8 & 6 & 10,3 & 3,31 & 0,95 \\
\hline To cast laying & 4 & 6,9 & 11 & 19,0 & 15 & 25,9 & 21 & 36,2 & 7 & 12,1 & 3,27 & 1,12 \\
\hline To make cuts & 7 & 12,1 & 6 & 10,3 & 13 & 22,4 & 20 & 34,5 & 12 & 20,7 & 3,41 & 1,27 \\
\hline To plan manufacturing & 7 & 12,1 & 12 & 20,7 & 17 & 29,3 & 19 & 32,8 & 3 & 5,2 & 2,98 & 1,11 \\
\hline To make matching & 2 & 3,4 & 3 & 5,2 & 11 & 19,0 & 28 & 48,3 & 14 & 24,1 & 4,53 & 5,22 \\
\hline To regulate & 3 & 5,2 & 5 & 8,6 & 15 & 25,9 & 24 & 41,4 & 11 & 19,0 & 3,60 & 1,05 \\
\hline To make markings & 2 & 3,4 & 2 & 3,4 & 9 & 15,5 & 21 & 36,2 & 24 & 41,4 & 4,08 & 1,01 \\
\hline $\begin{array}{l}\text { To use machinery- } \\
\text { equipment }\end{array}$ & 1 & 1,7 & 9 & 15,5 & 17 & 29,3 & 17 & 29,3 & 14 & 24,1 & 3,58 & 1,07 \\
\hline $\begin{array}{l}\text { To apply the suitable } \\
\text { sewing method }\end{array}$ & 4 & 6,9 & 5 & 8,6 & 19 & 32,8 & 21 & 36,2 & 9 & 15,5 & 3,44 & 1,07 \\
\hline $\begin{array}{l}\text { To apply suitable } \\
\text { embroidery style }\end{array}$ & 4 & 6,9 & 2 & 3,4 & 11 & 19,0 & 26 & 44,8 & 15 & 25,9 & 3,79 & 1,08 \\
\hline $\begin{array}{l}\text { To carry out ironing } \\
\text { procedures }\end{array}$ & - & - & 2 & 3,4 & 10 & 17,2 & 21 & 36,2 & 25 & 43,1 & 4,18 & 0,84 \\
\hline $\begin{array}{l}\text { To carry out product- } \\
\text { quality checks }\end{array}$ & 1 & 1,7 & 1 & 1,7 & 9 & 15,5 & 22 & 37,9 & 25 & 43,1 & 4,18 & 0,88 \\
\hline $\begin{array}{l}\text { To carry out proper } \\
\text { packaging }\end{array}$ & - & - & 1 & 1,7 & 10 & 17,2 & 23 & 39,7 & 24 & 41,4 & 4,20 & 0,78 \\
\hline $\begin{array}{l}\text { To carry out storing and } \\
\text { delivery procedures }\end{array}$ & 2 & 3,4 & 5 & 8,6 & 14 & 24,1 & 23 & 39,7 & 14 & 24,1 & 3,72 & 1,03 \\
\hline $\begin{array}{l}\text { To plan product } \\
\text { publicity }\end{array}$ & 7 & 12,1 & 4 & 6,9 & 21 & 36,2 & 16 & 27,6 & 10 & 17,2 & 3,31 & 1,20 \\
\hline $\begin{array}{l}\text { To be sensitive to the } \\
\text { health and } \\
\text { environmental } \\
\text { conditions }\end{array}$ & - & - & - & - & 11 & 19,0 & 20 & 34,5 & 27 & 46,6 & 4,27 & 0,76 \\
\hline $\begin{array}{l}\text { To be able to come up } \\
\text { with creative solutions }\end{array}$ & - & - & - & - & 11 & 19,0 & 20 & 34,5 & 27 & 46,6 & 3,63 & 1,19 \\
\hline
\end{tabular}

The grades between 1.00 and 1.80 are very poor; those between 1.81 and 2.60 are poor; those between 2.61 and -3.40 are medium; the grades between 3.41 and 4.20 are good; those between 4.21 and 5.00 are excellent.

Table 8. The distribution of the levels of Vocational Proficiency of the Students according to the corporations

When Table 8 is examined, the ready-to-wear corporations involved in the survey find the vocational high school students at medium and good levels in terms of designing models, 
preparing computer-based drafts and patterns, preparing a collection, preparing patterns, casting laying, making cuts, planning manufacturing, regulating, using machineryequipment, applying the suitable sewing method, carrying out storing and delivery procedures and planning product publicity.

Also in terms of making matching, making markings, applying suitable embroidery style, carrying out ironing procedures, carrying out product-quality checks, being sensitive to the health and environmental conditions and being able to come up with creative solutions, the ready-to-wear corporations involved in the survey find the vocational high school students at good and excellent levels.

Considering the arithmetic means calculated based on the answers received from ready-towear clothing corporations, vocational high school students can be said to have better proficiency in matching and being sensible for health and environmental conditions. According to the calculated means, they do not have any abilities in which they are very weak or weak (1.00 to 2.60 grades). However, when their proficiency levels are compared, it is observed that they are least proficient in manufacture planning with 2.98 mean.

When standard deviations pertaining to their vocational proficiency are taken into consideration, it is seen that the highest standard deviation is in matching ability with 5.22. This shows that there is a big difference among the students in matching abilities. Low standard deviations are seen in their abilities of being sensible for health and environmental conditions with 0.76 and making proper packaging with 0.78 . According to these data, they can be said to have similar abilities in these proficiencies.

The data revealed in Table 5 can be regarded as evidence showing that students of clothing at vocational training high schools largely meet the demand that ready-to-wear clothing industry has pertaining to vocational proficiency.

The data concerning the distribution of most important 5 changes emerging in their attitudes and abilities following their industrial practices are shown in Table 9.

\begin{tabular}{|l|l|l|}
\hline $\begin{array}{l}\text { Changes emerging in students' attitudes and abilities following } \\
\text { their industrial practices: }\end{array}$ & $\mathbf{f}$ & $\mathbf{\%}$ \\
\hline Their interest in job increased & 31 & 10,7 \\
\hline Their sense of responsibilities developed & 45 & 15,5 \\
\hline Their abilities in communication increased & 20 & 6,9 \\
\hline Their self-confidence in their jobs improved & 35 & 12,1 \\
\hline Their abilities in using machines and tools developed & 30 & 10,4 \\
\hline The speed they use machines and tools increased & 16 & 5,5 \\
\hline They became capable of working in any corporation & 17 & 5,9 \\
\hline They learned organizational-scheme in corporations & 22 & 7,6 \\
\hline They developed their theoretical and practical knowledge & 21 & 7,2 \\
\hline They got informed about ready-to-wear clothing industry & 21 & 7,2 \\
\hline They learned the process of manufacturing & 32 & 11,0 \\
\hline No change was observed & - & - \\
\hline Others & - & - \\
\hline TOTAL & $\mathbf{2 9 0}$ & $\mathbf{1 0 0 , 0}$ \\
\hline
\end{tabular}

Table 9. Distribution of 5 most important changes emerging in students' attitudes and abilities following their industrial practices 
When asked about 5 most significant changes in students' attitudes and abilities before and after their industrial practices, the corporations revealed that on top of the list with $16 \%$ was that their sense of responsibilities developed. In the second place with $12 \%$ was that their self -confidence in their jobs improved. In the third place with $11 \%$ was that their interest in job increased. In the fourth place with $10 \%$ was that their ability in using machines and tools developed. And in the fifth place with $8 \%$ was that they learned organizational-scheme in corporations. There was no corporation mentioning that there was any change in students' attitudes and abilities after their industrial practices.

Based on the data obtained from table 9, it can be said that industrial practices are influential in the development of students' attitudes and abilities, most effective being in developing in their sense of responsibility.

Data related to the distribution of 5 most important qualifications which, according to the corporations included in the survey, industrial practices provide for the students are shown in Table 10.

\begin{tabular}{|l|l|l|}
\hline Qualifications provided by industrial practices for the students & $\mathbf{f}$ & $\%$ \\
\hline They obtained a chance to work in real or real-like situations. & 45 & 15,5 \\
\hline $\begin{array}{l}\text { They were able to see , in real working conditions, the result of what } \\
\text { they did. }\end{array}$ & 27 & 9,3 \\
\hline $\begin{array}{l}\text { They got the opportunity to observe the process of manufacture and } \\
\text { management. }\end{array}$ & 37 & 12,8 \\
\hline $\begin{array}{l}\text { They got informed about issues like price, management, employer- } \\
\text { employee relations and legal rights and solidarity of employees. }\end{array}$ & 18 & 6,2 \\
\hline $\begin{array}{l}\text { Their adjustment period to their future profession is reduced by } \\
\text { providing them with a chance to observe improvements and methods } \\
\text { applied in the industry. }\end{array}$ & 17 & 5,9 \\
\hline They benefited from legal rights provided for the corporations. & 4 & 1,4 \\
\hline $\begin{array}{l}\text { They became able to observe and use the machines and tools in real } \\
\text { settings their schools didn't have. }\end{array}$ & 28 & 9,5 \\
\hline They began to believe in themselves. & 19 & 6,6 \\
\hline $\begin{array}{l}\text { They had the probability of comparing their knowledge gained in their } \\
\text { schools with the real world of industry. }\end{array}$ & 28 & 9,6 \\
\hline $\begin{array}{l}\text { By observing the real world of industry, they were able to evaluate } \\
\text { themselves and figure out what they lacked in. }\end{array}$ & 26 & 9,0 \\
\hline They became qualified for industrial discipline and business ethics. & 20 & 6,9 \\
\hline $\begin{array}{l}\text { They became aware of where they could find jobs when graduated from } \\
\text { schools. }\end{array}$ & 21 & 7,3 \\
\hline Others & - & - \\
\hline TOTAL & $\mathbf{2 9 0}$ & $\mathbf{1 0 0 , 0}$ \\
\hline
\end{tabular}

Table 10. According to corporations, the distribution of 5 significant qualifications students gained through industrial practices

When asked about 5 most significant qualifications of students, which industrial practices provided for them, the corporations revealed that for the students to obtain a chance to 
work in real or real-like situations was the most important with $16 \%$. The second most important as they revealed with $13 \%$ was that they got the opportunity to observe the process of manufacture and management. The third most important with $10 \%$ was that they had the chance to compare their knowledge gained at schools with the real world of industry. For the fourth most important with $9 \%$ was that they became able to observe and use the machines and tools in real settings their schools didn't have.The fifth most important qualification with $9 \%$ was that they were able to see, in real working conditions, the result of what they had already done.

When Table 10 is evaluated, it is seen that what industrial practices provide students as the most important qualification is that they have a chance to work in real or real-like situations. According to the corporations included in the survey, the data about the distribution of students' using machines and tools they hadn't encountered before are shown in Table 11.

\begin{tabular}{|l|l|l|}
\hline $\begin{array}{l}\text { Students' using machines and tools they hadn't } \\
\text { encountered before }\end{array}$ & $\mathbf{f}$ & $\mathbf{0}$ \\
\hline They used newly encountered machines in manufacturing. & 11 & 19,0 \\
\hline They experienced several trials. & 24 & 41,4 \\
\hline They never used but watched them work. & 20 & 34,5 \\
\hline They never used and never seen while working. & 1 & 1,7 \\
\hline Others & 2 & 3,4 \\
\hline TOTAL & $\mathbf{5 8}$ & $\mathbf{1 0 0 , 0}$ \\
\hline
\end{tabular}

Table 11. According to the corporations, the distribution of students' using machines and tools they had not encountered before.

When the distribution of students' using machines and tools they had not encountered before was evaluated, they revealed that $19 \%$ students used newly encountered machines in manufacturing, that $34 \%$ students never used them but watched them work, and that $41 \%$ students used several trials.

Based on the data obtained from Table 11, it is observed that students used newly encountered machines in manufacturing only slightly. We have the opinion that such a case stemmed from the fact that students were not allowed in this respect.

\subsection{Findings pertaining to the necessity and the participation of coordinator instructors employed in industrial practices}

According to the corporations included in the survey, the data about the distribution of the frequency of instructor's visit are shown in Table 12.

\begin{tabular}{|l|l|l|}
\hline $\begin{array}{l}\text { The frequency of coordinator } \\
\text { instructor's visit to corporations }\end{array}$ & $\mathbf{f}$ & $\mathbf{\%}$ \\
\hline Everyday & 1 & 1,7 \\
\hline Once in two days & 1 & 1,7 \\
\hline Once a week & 31 & 53,4 \\
\hline Once a month & 15 & 25,9 \\
\hline When it is necessary & 9 & 15,5 \\
\hline
\end{tabular}




\begin{tabular}{|l|l|l|}
\hline At the end of the year & - & - \\
\hline Never & 1 & 1,7 \\
\hline TOTAL & $\mathbf{5 8}$ & $\mathbf{1 0 0 , 0}$ \\
\hline
\end{tabular}

Table 12. The distribution of the frequency of instructor's visit according to the corporations.

When Table 12 is examined, nearly $53 \%$ of the instructors visited corporations once a week, and nearly $26 \%$ of the instructors visited them once a month.

Findings related to the distribution of the reasons necessitating coordinator instructor's visit according to the corporations included in the survey are shown in Table 13.

\begin{tabular}{|l|l|l|}
\hline $\begin{array}{l}\text { Reasons necessitating coordinator instructor's visit to corporations } \\
\text { where students had industrial practices }\end{array}$ & $\mathbf{f}$ \\
\hline $\begin{array}{l}\text { Coordinator instructors should help corporation personnel better } \\
\text { understand the practices, principles and purposes regarding the } \\
\text { training with which schools and corporations collaborate. }\end{array}$ & 43 & 14,7 \\
\hline $\begin{array}{l}\text { Coordinator instructors should help employers fulfill legal } \\
\text { requirements of corporations. }\end{array}$ & 17 & 5,9 \\
\hline $\begin{array}{l}\text { Coordinator instructors collaborating with experienced trainers } \\
\text { should devise training programs for every student. }\end{array}$ & 26 & 9,0 \\
\hline $\begin{array}{l}\text { Coordinator instructors should develop educational qualifications of } \\
\text { experienced trainers. }\end{array}$ & 10 & 3,5 \\
\hline $\begin{array}{l}\text { They should collect the data, which contribute to the evaluation of } \\
\text { students. }\end{array}$ & 37 & 12,8 \\
\hline They should determine extra knowledge to equip students with. & 29 & 10,0 \\
\hline $\begin{array}{l}\text { They should determine whatever extra measurements for the training } \\
\text { at school are. }\end{array}$ & 26 & 9,0 \\
\hline $\begin{array}{l}\text { They should clarify whether there is any change in the manufacture } \\
\text { plan of a student. }\end{array}$ & 22 & 7,6 \\
\hline They should evaluate efficiency of programs. & 40 & 13,7 \\
\hline $\begin{array}{l}\text { They should maintain security and determine whether legal } \\
\text { requirements are fulfilled. }\end{array}$ & 22 & 7,6 \\
\hline $\begin{array}{l}\text { They should keep peace by meeting them when problems with } \\
\text { experienced instructors exist. }\end{array}$ & 18 & 6,2 \\
\hline Others & $\mathbf{2 9 0}$ & $\mathbf{1 0 0 , 0}$ \\
\hline TOTAL
\end{tabular}

Table 13. The Distribution Of Reasons Necessitating Coordinator Instructor Visit To Corporations Where Students Had Industrial Practices

When asked about 5 most significant reasons necessitating coordinator instructor's visit to corporations where students had industrial practices, the corporations revealed that they should help corporation's personnel better understand the practices, principles and purposes regarding the training for which schools and corporations collaborate, which was the most important with $15 \%$. The second most important reason, as they revealed, with 14 $\%$ was that they should evaluate the efficiency of the programs. The third most important 
with $13 \%$ was that they should collect the data, which contribute to the evaluation of students. For the fourth most important with $10 \%$ was that they should determine extra knowledge to equip students with. The fifth most important reason with $9 \%$ was that coordinator instructors collaborating with experienced trainers should devise training programs for every student, and they should determine whatever extra measurements for the training at school were.

\subsection{Advantages and disadvantages of industrial practices for ready-to-wear corporations}

According to the corporations included in this study, the data related to the distribution of 5 important advantages of industrial practices for the corporations are shown in Table 14.

\begin{tabular}{|l|l|l|}
\hline Advantages of industrial practices for the corporations & $\mathbf{f}$ & $\%$ \\
\hline $\begin{array}{l}\text { Industrial practices help raise qualified staff in the way the industry } \\
\text { demands. }\end{array}$ & 39 & 13,5 \\
\hline $\begin{array}{l}\text { Industrial practices help produce in their workplace possible future } \\
\text { candidates who are likely to work in the sector. }\end{array}$ & 41 & 14,1 \\
\hline $\begin{array}{l}\text { Because they work mutually with schools, training at schools would } \\
\text { better meet the need of corporations. }\end{array}$ & 25 & 8,6 \\
\hline With the help of students, corporations learn advanced techniques. & 13 & 4,5 \\
\hline It contributes model development and design. & 15 & 5,2 \\
\hline $\begin{array}{l}\text { With the students taking part in manufacturing, manufacturing } \\
\text { increases. }\end{array}$ & 26 & 9,0 \\
\hline Overwork diminishes. & 15 & 5,2 \\
\hline Corporations benefit from paid taxes. & 7 & 2,4 \\
\hline They are subsidized for the training they complete. & 15 & 5,1 \\
\hline They develop public relations. & 20 & 6,9 \\
\hline $\begin{array}{l}\text { Industrial practices help the corporations employ far fewer } \\
\text { employees and thus decrease the costs. }\end{array}$ & 12 & 4,2 \\
\hline Time is governed in an economical way. & 16 & 5,5 \\
\hline Workflow gets much higher. & 25 & 8,6 \\
\hline $\begin{array}{l}\text { Industrial practices provide flexibility to meet the abrupt labor } \\
\text { demand of corporation. }\end{array}$ & 21 & 7,2 \\
\hline Others & - & - \\
\hline TOTAL & $\mathbf{2 9 0}$ & $\mathbf{1 0 0 , 0}$ \\
\hline
\end{tabular}

Table 14. According to the corporations, the distribution of 5 important advantages of industrial practices for the corporations

When asked about 5 most significant advantages of industrial practices for the corporations, the corporations revealed that industrial practices helped produce in their workplace possible future candidates who are likely to work in the sector, which was the most important with $14 \%$.

The second most important advantage, as they revealed, with $14 \%$ was that industrial practices helped raise qualified staff in the way the industry demanded. The third most 
important with $9 \%$ was that with the students taking part in manufacturing, manufacturing increased. For the fourth most important with $9 \%$ was that workflow got much higher. The fifth most important advantage was that industrial practices provided flexibility to meet the abrupt labor demand of corporation.

According to the corporations included in this study, the data related to the distribution of students' contribution to the corporations during industrial practices are shown in Table 15.

\begin{tabular}{|l|l|l|}
\hline $\begin{array}{l}\text { Students' contribution to the corporation during industrial } \\
\text { practices }\end{array}$ & $\mathbf{f}$ & $\mathbf{0}$ \\
\hline $\begin{array}{l}\text { They brought new applications and techniques to the } \\
\text { corporation. }\end{array}$ & 18 & 11,4 \\
\hline They helped the corporations develop new models and designs & 26 & 16,4 \\
\hline They increased production rate. & 35 & 22,0 \\
\hline They helped corporations reduce their expenditures. & 42 & 26,3 \\
\hline They had a positive influence in production quality. & 25 & 15,7 \\
\hline Others & 13 & 8,2 \\
\hline TOTAL & $\mathbf{1 5 9}$ & $\mathbf{1 0 0 , 0}$ \\
\hline
\end{tabular}

Table 15. According to the corporations, students' contribution to the corporation during industrial practices

When asked about Students' 3 most significant contributions to the corporations during industrial practices, the corporations revealed that they helped corporations reduce their expenditures, which was the most important with $26 \%$. The second most important contribution, as they revealed, with $22 \%$ was that they increased production rate. The third most important contribution with $16 \%$ was that they helped the corporations develop new models and designs.

According to the corporations included in this study, the data related to the distribution of inconveniences of industrial practices for the corporations are shown in Table 16.

\begin{tabular}{|l|l|l|}
\hline Inconveniences of corporations in accepting students & $\mathbf{f}$ & $\mathbf{0}$ \\
\hline $\begin{array}{l}\text { Students caused distraction to workers and so lowered their } \\
\text { performance and production quality. }\end{array}$ & 32 & 18,4 \\
\hline $\begin{array}{l}\text { They set bad examples for the workers because of being lack in } \\
\text { punctuality for the working hours. }\end{array}$ & 40 & 23,0 \\
\hline $\begin{array}{l}\text { They caused increasing costs (in meal, transportation, even in } \\
\text { production...etc.). }\end{array}$ & 46 & 26,5 \\
\hline $\begin{array}{l}\text { They led to an increase in poor quality product rate because they } \\
\text { usually lacked in advanced skills. }\end{array}$ & 47 & 27,0 \\
\hline Others & 9 & 5,1 \\
\hline TOTAL & $\mathbf{1 7 4}$ & $\mathbf{1 0 0 , 0}$ \\
\hline
\end{tabular}

Table 16. According to the corporations, the distribution of inconveniences of industrial practices for the corporations 
When asked about 3 most significant inconveniences of industrial practices for the corporations, the corporations revealed that they led to an increase in poor quality product rate because the students usually lacked in advanced skills, which was the most important inconvenience with $27 \%$. The second most important inconvenience, as they revealed, with $26 \%$ was that they caused to increase costs (in meal, transportation, even in production...etc.). The third most important inconvenience with $23 \%$ was that they set bad examples for the workers because of being lack in punctuality for the working hours.

\subsection{According to the industrialists, problems encountered during industrial practices and suggestions to increase efficiency rate}

According to the corporations included in the survey, the data related to the distribution of most frequent problems encountered during industrial practices are shown in Table 17.

\begin{tabular}{|l|l|l|}
\hline The problems mostly encountered during industrial practices & $\mathbf{f}$ & $\%$ \\
\hline $\begin{array}{l}\text { Settings the law necessitates couldn't be maintained in the survival of } \\
\text { collaborations between schools and industries. }\end{array}$ & 18 & 6,2 \\
\hline $\begin{array}{l}\text { Wages initially thought to be paid to students during industrial } \\
\text { practices were too low in some corporations and in some other } \\
\text { corporations the wages were never paid whatsoever. }\end{array}$ & 16 & 5,5 \\
\hline Concentration of the workers lessened because of the students. & 18 & 6,2 \\
\hline $\begin{array}{l}\text { There emerged irregularities in workflow stemming from the } \\
\text { motivation of students towards work in different departments. }\end{array}$ & 23 & 8,0 \\
\hline Misbehavior and bad attitude of the staff towards the students & 16 & 5,5 \\
\hline $\begin{array}{l}\text { Product quality was adversely affected since students, from time to } \\
\text { times, took part in manufacturing processes. }\end{array}$ & 18 & 6,2 \\
\hline Problems occurred in the behavior of corporation personnel. & 11 & 3,8 \\
\hline $\begin{array}{l}\text { The same qualifications could not be attained in the same level for } \\
\text { every student in industrial practices. }\end{array}$ & 30 & 10,4 \\
\hline Students had adjustment problems to work. & 30 & 10,4 \\
\hline Problems with transportation of students & 20 & 6,9 \\
\hline Problems with students behavior & 17 & 5,9 \\
\hline $\begin{array}{l}\text { Students had adaptation problems to the working regulations in } \\
\text { corporations. }\end{array}$ & 15 & 5,1 \\
\hline Students had problems in using technological equipment and tools. & 20 & 6,9 \\
\hline $\begin{array}{l}\text { No absolute uniformity could be maintained in training programs } \\
\text { conducted in schools and industry. }\end{array}$ & 18 & 6,2 \\
\hline Indifference of coordinator instructors & 7 & 2,4 \\
\hline $\begin{array}{l}\text { Parties concerned could not get ready sufficiently for training process } \\
\text { requiring collaborations. }\end{array}$ & 8 & 2,7 \\
\hline Parental problems & 5 & 1,7 \\
\hline Others & $\mathbf{2 9 0}$ & $\mathbf{1 0 0 , 0}$ \\
\hline TOTAL & probs & $\mathbf{m}$ \\
\hline
\end{tabular}

Table 17. According to the corporations, the distribution of the problems mostly encountered during industrial practices. 
When asked about 5 most significant problems mostly encountered during industrial practices, the ready-to-wear clothing corporations revealed that the same qualifications couldn't be attained in the same level for every student in industrial practices, which was the most important problem with $10 \%$. The second most important problem, as they revealed, with $10 \%$ was that students had adjustment problems to work. The third most important problem with $8 \%$ was that there emerged irregularities in workflow stemming from the motivation of students towards work in different departments. For the fourth most important with $7 \%$ was that problems with transportation of students. The fifth most important problem with about $7 \%$ was that students had problems in using technological equipment and tools.

According to the corporations included in the survey, the data related to the distribution of suggestions required for more efficient and qualified industrial practices are shown in Table 18.

\begin{tabular}{|l|l|l|}
\hline $\begin{array}{l}\text { Suggestions required for more efficient and qualified industrial } \\
\text { practices }\end{array}$ & $\mathbf{f}$ & $\mathbf{\%}$ \\
\hline $\begin{array}{l}\text { The number of the students that are sent to each corporation } \\
\text { should be reduced. }\end{array}$ & 14 & 4,8 \\
\hline Industrial practice period should be longer. & 33 & 11,4 \\
\hline Probationary period should be shorter. & 12 & 4,1 \\
\hline $\begin{array}{l}\text { Education at schools should be configured according to the } \\
\text { industrial practices at corporations. }\end{array}$ & 51 & 17,6 \\
\hline Regular work programs should be devised in corporations. & 42 & 14,5 \\
\hline $\begin{array}{l}\text { Technical personnel should be present to help trainee students at } \\
\text { corporations. }\end{array}$ & 40 & 13,8 \\
\hline $\begin{array}{l}\text { Efficient and regular supervision should be conducted by the } \\
\text { coordinator instructors. }\end{array}$ & 41 & 14,1 \\
\hline Balanced working conditions at corporations should be provided. & 47 & 16,2 \\
\hline Others & 10 & 3,5 \\
\hline TOTAL & $\mathbf{2 9 0}$ & $\mathbf{1 0 0 , 0}$ \\
\hline
\end{tabular}

Table 18. the distribution of the suggestions made by the corporations involved in the study for the industrial practices to have more efficiency and quality

The corporations stated their suggestions in order of importance as follows;

The foremost suggestion with $18 \%$ was that the training at schools should be restructured in accordance with the practices in corporations. In the second place with $16 \%$ came the suggestion that a harmonious working environment should be created in corporations. In the third place with $15 \%$ came the suggestion that a regular working program should be developed. In the fourth place with $14 \%$ was the suggestion that an effective and continuous supervision should be done by coordinator instructors. In the fifth place with 13 $\%$ was the suggestion that in corporations technical personnel qualified enough to help students with industrial practices in corporations should be employed. 


\section{Conclusion}

The findings of this study, which comprise the evaluations of those corporations on the industrial practices of vocational high school students who get clothing training in Turkey, are quite significant in order to examine their practices well and overcome the inadequacies. Because of the law 3308, school-industry relations in Turkey are regarded in a very narrow sense as only sending students to corporations to enable them to practice. Other types of relations are not developed sufficiently either. The centralist structure of Ministry of National Education prevents the development of these relations. Schools cannot be as sufficiently flexible as industry demands, and they cannot make a quick decision to solve the problems.

In this study, it has been shown that corporations generally establish regular relations with schools, but most of them do not know well the arrangements of industrial applications in laws and regulations. In order to overcome this lack of information, it is quite clear that there is need for informational training that should be fulfilled by vocational educational institutions.

In the evaluations made by corporations on the level of vocational proficiency of the students, it has been determined that ready-to-wear clothing students in vocational schools have intermediate and high levels. Nevertheless, this result should be examined separately for each proficiency, and relevant school programs and curriculums should be improved in order for the students to gain these proficiencies at an advanced level.

In some corporations, it has been revealed that instead of professional trainers and mentors, managers of the corporations have been training the students in industrial practices. It is obvious that business managers who have to execute a variety of duties cannot give the required guidance to the students. For this reason, to increase the quality of industrial practices, it is important that who will give the guidance to the students in corporations should be those who are specifically trained for this job, and the inspection of this should be done regularly.

It has been determined that those coordinator instructors chosen-by the law-among the teachers working at vocational high schools to plan the industrial practices mostly visit the corporations only once a week. According to the corporations, coordinator instructors have to visit workplaces for the following five reasons: 1 . to inform well the staff about the main purposes, principles, and the general applications regarding the training program executed by both corporations and schools. 2. to evaluate the efficiency of the program. 3. to gather information that would contribute to the evaluation of students' practices. 4 . to determine additional package of knowledge that should be given to the students. 5. to develop a training plan for each individual student by working together with experienced trainers. According to this result, corporations expect the most importantly that coordinator instructors inform adequately the staff working at workplace. Corporations also expect industrial practices to be evaluated both for programs and for students, and the needed work to be done in order to overcome inadequacies.

According to ready-to-wear clothing corporations, after industrial practices, students go mainly through the following positive changes: They develop a sense of responsibility; their confidence in themselves increases; they learn how the manufacturing processes go on, they become more interested in works, and their abilities and skills improve in operating machines used in their professions. Besides, according to corporations, by industrial practices students are able to find the opportunity to work in real or close-to-real working 
conditions; they can become familiar with production and administration processes; they are able to observe that the knowledge they gain at school is to what extent compatible with the real life conditions; they are able to use the equipment that their schools do not have; and they are able to see the results of what they do and how the results are used in real conditions. These improvements contributing to students' abilities and skills can be considered as an indication that vocational training program executed by vocational high schools and corporations has reached its goal.

According to ready-to-wear clothing corporations, industrial applications also provide the following opportunities for the enterprises: to train young students who will work in corporations in the future before they graduate; to contribute to students' training in accordance with what the corporations expect for prospective staff / workers; to increase the production through students' participation during industrial practices; to maintain continuity of production and be flexible enough to provide instant work force when needed. Hence, it is clear that industrial applications make significant contributions possible not only for students' vocational training but also for corporations that host these trainings. This application bears importance for the future of these enterprises too.

Some disadvantages of industrial application for corporations have also been determined: The application may cause an increased rate of low quality products because of students' lack of experience; it may cause an increased overall cost because of providing meal, transportation to students and of defective products they produce; and students may present bad example for the workers because of students' carelessness about working hours. These issues can be solved by positive attempts of corporations and schools.

According to corporations, the most common problems in industrial practices are respectively as follows: students' incapability of gaining the same level of abilities and skills; students' maladjustment to job, irregularity at work because of students' wishes to work at different units; the problems regarding the transportation of students; and the predicaments students face when using technological equipment. According to this result, the most important problem in industrial applications expressed by corporations is that equal improvement of vocational abilities and skills cannot be made common among students. It is true that in every educational system, this problem emerges because of students' individual difference. The chief goal should be to apply training programs that is aware of these individual differences. During industrial practices, trainers' arrangement and use of curriculum that is aware of students' individual differences and success levels will play an important role in improvements of each student's vocational abilities and skills. Furthermore, programs and curriculums that canalize students to subunits in the same vocational branch by regarding their individual differences and concerns will provide contributions both to students' vocational development and corporations' finding staff and workers who are suitable for working conditions.

According to corporations, for industrial practices to be more productive and have high quality, the followings should be done: Programs and curriculums applied at school should be re-structured in accordance with the practices at corporations; a harmonious atmosphere should be provided at corporations; a regular working program should be developed; an effective and continuous supervision should be done by coordinator instructors; and enough technical staff should be available to help students' needs.

Based on the results gained through this study, we can make the following suggestions: 
- Corporations and schools must establish regular relations with each other not only in industrial applications but also in other areas as well.

- Corporations that admit students for industrial practices must be informed adequately about legal regulations on vocational and technical education.

- Suggestions made by corporations on training programs and curriculums applied at schools must be evaluated seriously by school managements.

- Some control studies and works should be done in vocational high schools to develop students' vocational skills at a better level.

- Coordinator instructors should visit corporations more often than they do.

- More effective and continuous supervision should be done by coordinator instructors.

- In those places where industrial practices are made, more affective supervision should be done on a regular basis.

- Because students experience problems of maladjustment to job, they should be prepared for industrial practices by their teachers before the practices begin.

- In corporations, enough number of technical staff and trainers who are capable of helping students should be available to help students in industrial practices.

- Regular and effective training programs should be developed in corporations.

- In corporations, distinct training programs should be set for each student in accordance with their individual differences and success levels.

\section{References}

Ağaç, S. (2004). Gazi Üniversitesi Mesleki Eğitim Fakültesi Giyim Endüstrisi ve Moda Tasarımı Eğitimi Bölümü Öğrencilerinin Yaz Dönemi Stajına İlişkin Memnuniyet Durumlarının Belirlenmesi Üzerine Bir Araştırma [A Survey on Determining the Level of Satisfaction Related To Summer-Time Training of The Students at Clothing Industry and Fashion Design Training Department Of Gazi University], Mesleki Ĕ̈itim Dergisi, pp. 166-178, Ankara.

Alkan, C.; Doğan, H. \& Sezgin, İ. (2007). Mesleki ve Teknik Eğitimin Esasları[The fundamentals of Vocational and Technical Training], $p p$. 12-18, İstanbul.

Doğan, H.; Ulusoy, A. \& Hacioğlu, F. (1997). Okul Sanayi İlişkileri [School-Industry Relations], pp.5-23, Ankara.

Ekinci, Y. (1990) Ahiliğin Işığında Türkiye'de Cumhuriyet Dönemi Meslek Eğitimi [Vocational Training in Turkey During the Republican Period in the Light of Akhism], Ahilik ve Meslek Eğitim,pp. 108-125, Ankara

Erkan, S.(1995) Endüstriyel Gelişim Aşamasında İşsizlik Probleminin Yoğun Olarak Yaşandığı Türkiye'de İstihdamın Arttırılmasında Yaygın ve Örgün Eğitimin Fonksiyonu[The Function of Formal and Informal Education in Increasing Employment in Turkey, Where Unemployment Problems Are Felt Intensively in the Period of Industrial Development], Milli Eğitim Dergisi, Sayı: 128, pp. 45-49, Ankara

Erkal, M. E. (1978). Orta Teknik Eğitim-Sanayi İlişkileri [Secondary Technical Education and Industry Relations], pp. 102-108, İstanbul.

Günceoğlu, B. (2003) METGE projesi Kapsamında Uygulanan Makine İşlemleri Meslek Programının Değerlendirilmesi [The Evaluation of Machine Processes Vocational 
Programs Applied under METGE; Vocational and Technical Training Improvement Project], Milli Eğitim Dergisi, pp. 157,Ankara

Gürol, M. (1997). Okul Sanayi İşbirliği [School-Industry Relations], pp. 87-92, Ankara.

İmer, A. (2007) Türk Hazır Giyim Sektörünün Markalaşma Sürecinde Mesleki Eğitimin Rolü [The Role of Vocational Training in the Course of Turkish Ready-to-wear Clothing Sector becoming a Trademark], Mesleki Eğitim Fakültesi Dergisi, 2/2 Ocak, pp. 76-83, Ankara

Kappler, W. (1991) Dual Eğitim Sisteminin Yapısı, Şartları ve Bunların Türkiye'de Uyarlanmas1[The Structure of Dual Training System, its Requirements and their Adaptation in Turkey], Türkiye'de İşletmelerde Mesleki Eğitim Paneli, pp. 38-52, Ankara.

Kaya, H. (2004). Eğitim Kurumu-İşletme Diyaloğu Uluslar arası Konferansı[the International Dialogue conference on the institutions of education-corporations], pp. 63-75, Ankara

Kılınç, S. (2004) İnsan Kaynakları Eğitimi[Education of Human Sources], Mesleki ve Teknik Eğitimi Geliştirme Projesi Kapanış Raporu, pp. 48-54, Ankara

Koç, F. \& Bölükbaşı, A. (2006) Tekstil-Konfeksiyon Öğretim Programında Kazandırılan Teknik Bilgi ve Becerilerin İş Hayatındaki Uygulamalarla Tutarlılığı [The Coherence of Proficiencies and Abilities gained from Textile-Ready to Wear Educational Programs with the Applications in Working Life], Mesleki Eğitim Fakültesi Dergisi, 1/1 Temmuz, pp. 27-38, Ankara

Kraska, M. F. (1995) Amerikada Mesleki ve Teknik Eğitimin Gelişimi [The Development of Vocational and Technical Education in America], çev: Tayyip Duman, Milli Eğitim Dergisi, Sayı:128, pp. 102-125 Ankara

Kuru, S. \& Korkmaz, M. (2006) Meslek Yüksekokulu Hazır Giyim Programı Öğrencilerinin Meslek Stajlarındaki Yeterliliğin Akademik Personel Açısından Değerlendirilmesi [The Evaluation of Proficiencies of Students in Vocational Collages in the Department of Ready-to-Wear Programs from the view of Academicians], Konfeksiyon Teknoloji Dergisi, Sayı:45, pp. 28-32.

Schmidt, H. (1991) Almanya Federal Cumhuriyetindeki Eğitim Sistemi[ The system of Education in Federal Republic of Germany], pp. 27-32, Ankara.

Şahinkesen, A. (1991) Eğitimde İkili Sistem[ The Dual System in Training], İzmir 1. Eğitim Kongresi Bildirileri, pp. 87-92, İzmir.

Topal, B. (1995) Mesleki ve Teknik Eğitimde İşgücü ve İstihdam Problemleri[ The Problems of Labor Force and Empleyment in Vocational and Technical Training], Mesleki ve Teknik Ĕ̈itim Sempozyumu, pp. 28-37, Elazı̆

Ulusoy, A. (2004) Kalifiye İsgü̈cünün Yetiştirilmesinde Ĕ̆itim Kurumu-İşletme İşbirliği: Türkiye Uygulaması [The institution of Training-Corporation Relations in Raising Qualified Labor Force: The Case in Turkey], 12-45, Ankara 


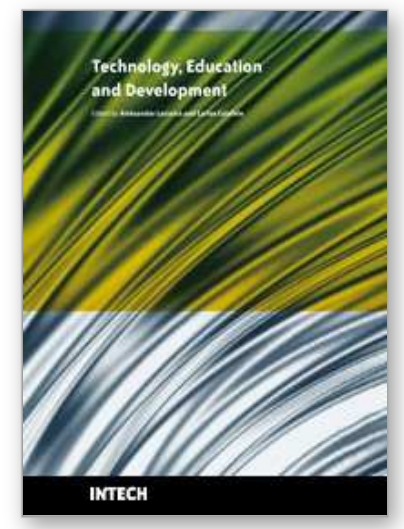

\author{
Technology Education and Development \\ Edited by Aleksandar Lazinica and Carlos Calafate
}

ISBN 978-953-307-007-0

Hard cover, 528 pages

Publisher InTech

Published online 01, October, 2009

Published in print edition October, 2009

The widespread deployment and use of Information Technologies (IT) has paved the way for change in many fields of our societies. The Internet, mobile computing, social networks and many other advances in human communications have become essential to promote and boost education, technology and industry. On the education side, the new challenges related with the integration of IT technologies into all aspects of learning require revising the traditional educational paradigms that have prevailed for the last centuries. Additionally, the globalization of education and student mobility requirements are favoring a fluid interchange of tools, methodologies and evaluation strategies, which promote innovation at an accelerated pace. Curricular revisions are also taking place to achieved a more specialized education that is able to responds to the society's requirements in terms of professional training. In this process, guaranteeing quality has also become a critical issue. On the industrial and technological side, the focus on ecological developments is essential to achieve a sustainable degree of prosperity, and all efforts to promote greener societies are welcome. In this book we gather knowledge and experiences of different authors on all these topics, hoping to offer the reader a wider view of the revolution taking place within and without our educational centers. In summary, we believe that this book makes an important contribution to the fields of education and technology in these times of great change, offering a mean for experts in the different areas to share valuable experiences and points of view that we hope are enriching to the reader. Enjoy the book!

\title{
How to reference
}

In order to correctly reference this scholarly work, feel free to copy and paste the following:

Nurgul Kilinc and Meral Akkaya (2009). From the Point of View of Ready-to-Wear Industrial Practices of the Vocational High School Students Getting Clothing Education in Turkey, Technology Education and Development, Aleksandar Lazinica and Carlos Calafate (Ed.), ISBN: 978-953-307-007-0, InTech, Available from: http://www.intechopen.com/books/technology-education-and-development/from-the-point-of-view-ofready-to-wear-industrial-practices-of-the-vocational-high-school-students-

\section{INTECH}

open science | open minds

\section{InTech Europe}

University Campus STeP Ri

Slavka Krautzeka 83/A

51000 Rijeka, Croatia

Phone: +385 (51) 770447

\section{InTech China}

Unit 405, Office Block, Hotel Equatorial Shanghai

No.65, Yan An Road (West), Shanghai, 200040, China

中国上海市延安西路65号上海国际贵都大饭店办公楼 405 单元

Phone: +86-21-62489820 
Fax: +385 (51) 686166

Fax: +86-21-62489821

www.intechopen.com 
(C) 2009 The Author(s). Licensee IntechOpen. This chapter is distributed under the terms of the Creative Commons Attribution-NonCommercial-ShareAlike-3.0 License, which permits use, distribution and reproduction for non-commercial purposes, provided the original is properly cited and derivative works building on this content are distributed under the same license. 